\title{
Morphogenetic Protein rhBMP-2 and New Bone Formation
}

\author{
Proteína Morfogenética rhBMP-2 y Tejido Ósteoneoformado \\ "João Paulo Mardegan Issa; "Cássio do Nascimento; * Rodrigo Edson dos Santos Barbosa; \\ ${ }^{* *}$ Amaro Sérgio da Silva Mello \& ${ }^{* * *}$ Mamie Mizusaki Iyomasa
}

ISSA, M. J. P.; NASCIMENTO, C.; BARBOSA, S. R. E.; MELLO, S. A. S. \& IYOMASA, M. M. Morphogenetic protein rhBMP2 and new bone formation. Int. J. Morphol., 24(3):323-330, 2006.

SUMMARY: This work aim to show by literature review the principal characteristics of morphogenetic proteins, in special of the rhBMP-2, with the major osteoinductive properties, presented in the prime works count from it discovery until actually, showing the most varieties and applications of this protein.

KEY WORDS: Bone; Morphogenetic protein; rhBMP-2.

\section{INTRODUCTION}

Over than thirty years, most researches have been realized with the objective to identify proteins capable to induce new bone formation and standard methods of biological application that can lead to decrease or elimination the bone graft (Nawata et al. 2005).

One decade ago, the bone morphogenetic proteins (BMPs) have been identified and purified from human bone matrix (Bessho et al. 1989). Since then, it has been identified 17 different proteins of the same family, that is, proteins with the same characteristics, some of synthesized by molecular biologic techniques, defined as recombinant human morphogenetic proteins or rhBMPs (Wozney, 1989; Celeste et al., 1994; Urist, 1997; Bouxsein et al., 2001). These BMPs belong to TGF growth factor superfamily, that involves polypeptides with common structural characteristics (Kingsley, 1994) and that have an important role in progenitor cells migration, mesenchymal cells proliferation, osteogenic and chondrogenic cells differentiation, vascular invasion and bone remodeling (Reddi, 1997; Rauch et al., 2000; Spector et al., 51, 2001).

Thus, the aim of this work is to present, by a literature review, the principal characteristics of bone morphogenetic proteins, in special, the rhBMP-2, since its discovery until the present time, and describe the most varies uses of this protein.

\section{DISCUSSION}

Bone morphogenetic protein characterization. Bone morphogenetic proteins have proliferative effects on different cellular types, showing chemotactic properties and being able to induce mesenchymal cells differentiation into osteoblastic and chondroblastic line cells (Reddi \& Cunningham, 1993). Moreover, BMPs are powerful inductive of the osteogenic activity during the embryologic bone formation phase and in bone healing cases (Hogan, 1996; Rosen et al., 1996). Among members of the extensive family of these proteins, the BMP-2, 4 and 7 have been demonstrated an important role on osteogenic process (Hogan; Rosen et al.).

The availability of recombinant human bone morphogenetic proteins allowed proving osteoinductive properties of these proteins, as well as the detailed characterization of this activity in vivo. The rhBMP-2 was the first molecule studied in detail (Wang et al., 1990), being produced using Chinese hamster ovary cells. The purification and biochemical characterization of these molecules show that they are similar to BMP molecules found in bone (Israel et al., 1992; Inoda et al., 2004; Kamakura et al., 2004). The rhBMP-2 implantation in an ectopic delivery system, shows that this molecule is osteoinductive, proven by histologic exams, where the implantation of different doses in different wait periods shows that new bone process with the use of rhBMP-2 resulted to a cartilaginous bone, in the

* Student of Masters' Program in Oral Rehabilitation at Ribeirão Preto College of Dentistry - University of São Paulo (FORP-USP), Brasil.

** Professor of Oral Implantology at APCD - Ribeirão Preto, Brasil.

**** Professor of Morphological Sciences at Ribeirão Preto College of Dentistry - University of São Paulo (FORP-USP), Brasil.

This study was supported by FAPESP (No: 04/12013-0). 
first period and that only BMP molecule is capable to begin the new process in vivo. This study showed that BMP amount inserted is strongly related to new bone formation quantity, thus increasing the BMP quantity inserted, the new bone formation will occur faster. The bone healing can be observed in five days after the insertion, occurring this new bone formation concomitantly with the cartilaginous tissue formation, showing that the rhBMP-2 is capable to influence both, the cartilaginous and bone formation.

The BMP-2 use resulted in an increase on the BMP4 expression. The recombinant human (rhBMP-4) seems to have similar activity to BMP-2 in vivo, inducing bone and cartilage formation in rat experiments. The BMP-6 and BMP7 (Sampath et al., 1992), as well as the BMP-2 and BMP4 are osteoinductive and chondroinductive, but it is difficult to compare the relative activities of all these molecules, because the researches have been used different methods (Table I) (D’Alessandro et al., 1991; Cox et al., 1991).
Action mechanism of bone morphogenetic proteins. An in vivo studies it was verified that BMPs can induce the new bone formation and cartilaginous tissue by a process that still was not been clarified and that involves the activity of a great number of local and systemic growth factors. Studies that involve individual characterization of these proteins is complicated by two reasons: first, because little comparisons about the different BMP types have been realized in the same cellular groups, and second, some studies have been realized with BMPs deriving from purified bone tissue, that generally contain different types of BMP molecules.

The treatment with BMPs result in mesenchymal cells differentiation into different cellular morphotypes (Yamaguchi et al., 1991), an example, in C26 cells, the BMP-2 increase the alkaline phosphatase expression and the parathyroid hormone receptors $(\mathrm{PTH})$ and also the osteocalcin expression, a marker for osteoblast differentiation.

Table I. Bone morphogenetic protein m RNA tissue and cell line sources.

\begin{tabular}{|c|c|c|}
\hline BMP-2 & $\begin{array}{l}\text { Bone, spleen, liver, brain, } \\
\text { lung, kidney, heart, placenta. }\end{array}$ & $\begin{array}{l}\text { U-2 OS (osteosarcoma) } \\
\text { MG-63 (osteosarcoma) } \\
\text { F9 (embryonal carcinoma) }\end{array}$ \\
\hline BMP-3 & Lung, brain & $\begin{array}{l}\text { PC-3 (prostate) } \\
\text { H128 (small cell lung carcinoma) }\end{array}$ \\
\hline BMP-4 & $\begin{array}{l}\text { Bone, lung, kidney, brain, } \\
\text { spleen, liver, heart, placenta }\end{array}$ & $\begin{array}{l}\text { U-2 OS (osteosarcoma) } \\
\text { MG-63 (osteosarcoma) } \\
\text { PC-3 (prostate) } \\
\text { DU-145 (prostate) } \\
\text { F-9 (embryonal carcinoma) }\end{array}$ \\
\hline BMP-5 & Placenta & $\begin{array}{l}\text { U-2 OS (osteosarcoma) } \\
\text { MG-63 (osteosarcoma) }\end{array}$ \\
\hline BMP-6 & $\begin{array}{l}\text { Calvaria, lung, brain, } \\
\text { placenta, kidney, uterus, } \\
\text { muscle, skin }\end{array}$ & $\begin{array}{l}\text { U-2 OS (osteosarcoma) } \\
\text { F-9 (+ RA + cyclic adenosine monophosphate) } \\
\text { PC-3, DU-145, PAIII (prostate carcinomas) }\end{array}$ \\
\hline BMP-7 & $\begin{array}{l}\text { Kidney, placenta, brain, } \\
\text { calvaria, spleen, lung, heart, } \\
\text { liver, adrenal, bladder }\end{array}$ & U-2 OS (osteosarcoma) \\
\hline
\end{tabular}


Generally, in vitro BMPs have significant effects on cells in multiple periods of the new bone formation, as also observed in vivo studies.

Through chemotaxis, the BMPs can bring cells to implantation site and do with that undifferentiated mesenchymal cells become into specific cellular types that synthesize bone and cartilaginous tissue, as the osteoblast and chondroblast cells (Inoda et al.; Kamakura et al.).

In 1965, Marshall Urist discovered that decalcified bone matrix implanted at nonbone sites will induce the cartilaginous tissue and new bone formation (Urist, 1965). The author defined this process as autoinduction and later showed that protein extracts could be separate from decalcified bone and were responsible for this new bone formation (Urist et al., 1973). In this model, new bone was formed following events well characterized in endochondral ossification, with cartilaginous tissue formation before the new bone formation (Urist et al., 1979; Sampath \& Reddi, 1981).

Development of the recombinant human morphogenetic protein. Bone can be described as having three components: a mineral component, a collagenous matrix and a growth protein component. Using experimental models in rats, some authors decalcified and separated the bone tissue in a component that contains a collagenous matrix and other component that contains growth proteins. The protein component was reconstituted with inactive matrix and implanted ectopically. New bone was observed after ten days. This growth factor component was called bone morphogenetic protein (Urist et al., 1979; Sampath \& Reddi).

Although the BMP has the capacity to induce new bone formation, it is difficult to obtain this protein by a purification process because small amounts are present in bone. Recent advances in biological molecular techniques provided the production of a great quantity of recombinant human proteins, like BMPs.

The development of the recombinant proteins (rhBMPs) began by individual members isolation of the morphogenetic proteins superfamily. Most of these proteins are members of the beta transforming growth factors (TGF-b) that constitute a superfamily proteins based in the homology sequence of the primary amino acid (Celeste et al., 1990). The BMP-2 and BMP-4 recombinant are $92 \%$ identically and the BMP-5,6,7 e 8 are $82 \%$ identically (Wozney, 1995).
Isolating the BMPs in human corpses bone, only $0.1 \mu \mathrm{g}$ BMP per kilogram of bone can be obtained. Already the rhBMP-2 can be produced in abundance. This protein has non-antigenic and non-immunogenic properties, not having risk of human disease transference because it is a protein produced by bio-engineered methods (Genetics Institute, Cambridge Mass, unpublished reports, 1995).

The osteoinductive activity of recombinant human bone morphogenetic proteins (rhBMPs) was analyzed an in vivo studies (Fujimura et al., 1995; Kusumoto et al., 1995). Due to osteoinduction power observed in these studies, is clearly the potential of these proteins in a great number of clinical applications, like reconstructive surgeries, bone defects provoked by pathological processes and physiological bone loss (Johnson et al., 1988 a,b, 1990; Toriumi et al., 1991; Marden et al., 1994; Boyne, 1995).

Correlation between BMP and TGF-b. Despite of BMPs are members of the TGF-b superfamily, they have a few effects in common proven by in vitro studies in different cellular types. An example, TGF-b inhibit the phosphatase alkaline production in most cellular types, including C26, W-20-17 e MC3T3-E1 cells (Noda \& Rodan, 1986; Katagiri et al., 1990b), while BMPs have been increased in these cellular types. In contrast of BMPs, TGF-b suppresses the sulphate incorporation in any specific cellular types.

Proteins's carrier delivery. The morphogenetic protein of the classification 2, or rhBMP-2, has been desperted interests for clinical applications, for this differentiated capacity to induce ossification and being commercially available.

However, in vivo, the rhBMP-2 spreads out quickly from the implanted place, when deposited in solution, what shortens your osteinductor effects (Fujimura et al.). For this, recent studies have been demonstrated that the application of high dosages of these proteins directly on tissues is not so efficient in relation to osteogeneic induction, because occur a fast protein metabolization (Wang et al.) however, small dosages, but supported, seem to produce satisfactory results (Yasko et al., 1992; Gerhart et al., 1993; Lee et al., 1994; Bostrom et al., 1995). Thus, the presence of a biomaterial carrier can influence in quantity of the new bone formation and decrease the quantity of protein that is necessary for new bone formation induction. Therefore, the role of carrier matrix is to immobilize the protein in site that was implanted for a period 
sufficiently so that the cellular reply occurs.

Thus, substances capable to delivery BMPs to tissues for long periods, such as fibrin and collagen sponges, hydroxyapatite, calcium sulphate and synthetic materials like copolymers have been used as carriers in most studies (Kawamura et al., 1987; Yamazaki et al., 1988; Takaoka et al., 1988, 1991; Desilets et al., 1990; Ripamonti, 1991; Sato et al., 1991; Matsuo et al., 2003; Peterson et al., 2005).

However, properties as controlled resorption, adequate density to support soft tissues, supported drug delivery, facility in manipulation and application, are desirable properties, however not always found in currently available materials (Bessho \& Iizuka, 1995; Bessho et al., 2002; Keskin et al., 2005).

Treatments involving the use of the rhBMP-2. The effectiveness in use of the rhBMP-2, represented for the quantity and level of induction for the new bone formation is affected by the carrier that was used, animal specie and wait time until the animal sacrifice (Wozney, 1995; Zellin \& Lindhe, 1997). Yasko et al. showed that a dose of $11 \mu \mathrm{g}$ de rhBMP-2 for recovery a critical bone defect $(5 \mathrm{~mm})$ in rat femurs- Sprague-Dawley, resulted in significantly new bone formation, with mechanic, radiographic and histologic evidences, but one dose of $1,4 \mu \mathrm{g}$ produced new bone tissue but without these union evidences. Others studies also demonstrated that high rhBMP-2 levels are not effective, being of the carrier the role to provide a slow and gradual rhBMP-2 delivery (Zellin \& Lindhe).

Some experiments were realized with the objective to test osteoinduction ability of bone morphogenetic proteins in healing process of the critical bone defects realized in most varied animal species, between them, in rats (Doll et al., 1990; Mark et al., 1990), rabbits (Moore et al., 1990), dogs (Sato \& Urist, 1985; Urist et al., 1987b; Nilsson \& Urist, 1991), sheeps (Lindholm et al., 1988) and monkeys (Ferguson et al., 1987). In all these studies, it has indications that BMP molecules are very useful in treatment of innumerable clinical conditions where aim is the new bone formation (Einhorn, 1992).
As new classes of treatments are evaluated for efficacy, their safety must be assessed. Of the recombinant proteins, rhBMP-2 has had extensive toxicological evaluations in both preclinical and clinical studies. These studies included rhBMP-2 in single and multiple doses, as well as teratology and fertility studies. Dosages of rhBMP-2 were administered intra-venously (IV) and were similar or the same accross the studies. In all studies, the rhBMP-2 dosages (per kilogram of body weight) were selected to constitute a range that was slightly lower to substantially higher than the amount of rhBMP-2 used in human clinical trials.

In acute intra-venously single-dose studies of up to $5.3 \mathrm{mg} / \mathrm{kg}$ in the rat and $\mathrm{dog}$, there no deaths related to treatment and no treatment related changes were observed for body weight, food consumption, blood pressure, electrocardiogram, clinical chemistries or urinalysis (Schaub, 1993). In the 28 day study of rats, no adverse events were noted. In the beagle dog study, dosages of 0.016 to $0.16 \mathrm{mg} / \mathrm{kg}$ were administered intravenously daily for 28 days. Again, there were no treatment related changes in clinical signs, clinical chemistries or urinalysis.

In teratology studies in the rat and rabbit, treatment of gravid rats and rabbits with rhBMP-2 did not produce systemic maternal toxicity or gross fetal abnormalities at dosages up to $1.6 \mathrm{mg} / \mathrm{kg} /$ day. A rat fertility study showed no treatment related effects on maternal and paternal mating performance or reproductive parameter at dosages up to $0.16 \mathrm{mg} / \mathrm{kg} /$ day (Genetics Institute, Cambridge Mass, unpublished reports, 1995).

\section{CONCLUSIONS}

Therefore, despite the rhBMP-2 osteoinduction properties already to be know and proven, new surveys must be realized with the objective to find a carrier substance that presents these characteristics and provide a slow and gradual rhBMP-2 delivery, what it is essential to get the clinical effect desirable.

ISSA, M. J. P.; NASCIMENTO, C.; BARBOSA, S. R. E.; MELLO, S. A. S. \& IYOMASA, M. M. Proteína morfogenética rhBMP2 y tejido osteoformado. Int. J. Morphol., 24(3):323-330, 2006.

RESUMEN: Esta revisión de la literatura tiene como objetvo mostrar las principales características morfogenéticas, de la proteína rhBMP-2, de mayor prpiedad osteoinductiva, estudiados desde su descubrimiento hasta la actualidad, señalando las diferentes utilizaciones y aplicaciones de esta proteína.

PALABRAS CLAVE: Hueso; Proteína morfogenética; rhBMP-2. 


\section{REFERENCES}

Bessho, K; Tagawa, T. \& Murata, M. Purification of bone morphogenetics protein derived from bovine matrix. Biochem. Biophys. Res. Commun., 165:595-601, 1989.

Bessho, K. \& Iizuka, T. The possibility of application of bone morphogenetic proteins (BMPs) for reconstruction of jaw bones. Oral. Oncology., 4:304-7, 1995.

Bessho, K.; Carnes, D. L.; Cavin, R. \& Ong, J. L. Experimental studies on bone induction using low-molecularweight poly (DL-lactide-co-glycolide) as a carrier for recombinant human bone morphogenetic protein-2. $J$. Biomed. Mater. Res., 61:61-5, 2002.

Bostrom, M. P. G.; Lane, J. M. \& Berberian, W. S. Immunolocalization and expression of bone morphogenetic proteins 2 and 4 in fracture healing. $J$. Orthop. Res., 13:357-67, 1995.

Bouxsein, M. L.; Turek, T. J.; Blake, C. A.; Augusta, D. D.; Li, X.; Stevens, M.; Seeherman, H. J. \& Wozney, J. M. Recombinant human bone morphogenetic protein-2 accelerates healing in a rabbit ulnar osteotomy model. J. Bone \& Joint Surgery., 83A:1219-30, 2001.

Boyne, P. J. Reconstruction of discontinuity mandibular defects in rhesus monkeys using rhBMP-2. J. Oral. Maxillofac. Surg., 53:92, 1995.

Celeste, A.J.; Iannazzi, J.A.; Taylor, R.C.; Hewick, R.M., et al. Identification of transforming growth factor beta family members present in bone-inductive protein purified from bovine bone. Proc. Natl. Acad. Sci. USA., 87: 9843-47, 1990

Celeste, A. J.; Song, J. J.; Cox, K.; Rosen, V. \& Wozney, J. M. Bone morphogenetic protein-9, a new member of TGF-ß superfamily. J. Bone. Miner. Res., 9:136, 1994.

Cox, K.; Holtrop, M.; D’Alessandro, J. S.; Wang, E. A.; Wozney, J. M. \& Rosen, V. Histological and ultrastructural comparison of the in vivo activities of rhBMP-2 and rhBMP-5. J. Bone. Miner. Res., 6:155, 1991.

D’Alessandro, J. S.; Cox, K. A.; Israel, D. I.; Lapan, P.; Moutsatsos, I. K.; Nove, J.; Rosen, V.; Ryan, M. C.; Wozney, J. M. \& Wang, E. A. Purification, characterization and activities of recombinant bone morphogenetic protein 5. J. Bone. Miner. Res., 6:S153, 1991.
Desilets, C. P.; Marden, L. J.; Patterson, A. L. \& Hollinger, J. O. Development of synthetic bone-repair materials for craniofacial reconstruction. J. Craniofac. Surg., 1:1503, 1990 .

Doll, B. A.; Towle, H. J.; Hollinger, J.O.; Reddi, A. H. \& Melloning, J. T. The osteogenic potential of two composite graft systems using osteogenin. J. Periodontol., 61:745-50, 1990.

Einhorn, T. A. Clinical applications of recombinant gene technology: Bone and cartilage repair. Cells Materials., 2: 1-11, 1992.

Ferguson, D.; Davis, W. L.; Urist, M. R.; Hurt, W. C. \& Allen, E. P. Bovine bone morphogenetic protein (bBMP) fraction-induced repair of craniotomy defects in the Rhesus monkey. Clin. Orthop. Relat. Res., 219:251-90, 1987.

Fujimura, K.; Bessho, K.; Kusumoto, K.; Ogawa, Y. \& Iizuka, T. Experimental studies on bone inducing activity of composites of atelopeptide type collagen as a carrier for ectopic osteoinduction by rhBMP-2. Biochem. Biophys. Res. Commun., 208:316-22, 1995.

Genetics Institute, Cambridge Mass, unpublished reports. The creation of rhBMP-2 (recombinant human bone morphogenetic protein-2), 1995.

Gerhart, T. N.; Kirker-Head, C. A. \& Kriz, M. J. Healing segmental femoral defects in sheep using recombinant human bone morphogenetic protein. Clin. Orthop., 293:317-26, 1993.

Hogan, B. L. Bone morphogenetic proteins: Multifunctional regulators of vertebrate development. Genes Dev., 10:1580-94, 1996.

Inoda, H; Yamamoto, G; Hattori, T. Histological investigation of osteoinductive properties of rhBMP-2 in a rat calvarial bon defect model. J. Craniomaxillofac. Surg., 32:365-9, 2004.

Israel, D. I.; Nove, J.; Kerns, K. M.; Moutsatsos, I. K. \& Kaufman, R. J. Expression and characterization of bone morphogenetic protein-2 in Chinese hamster ovary cells. Growth Factors., 7:139-50, 1992.

Johnson, E. E.; Urist, M. R. \& Finerman, G.A.M. Bone 
morphogenetic protein augmentation grafting of resistant femoral nonunions: A preliminary report. Clin. Orthop. Relat. Res., 230:257-65, 1988 a.

Johnson, E. E.; Urist, M. R.; Finerman, G. A. M. Repair of segmental defects of the tibia with cancellous bone grafts augmented with human bone morphogenetic protein. Clin. Orthop. Relat. Res., 236: 249-57, 1988 b.

Johnson, E. E.; Urist, M. R. \& Finerman, G. A. M. Distal metaphyseal tibial nonunion: Deformity and bone loss treated by open reduction, internal fixation, and human bone morphogenetic protein (hBMP). Clin. Orthop. Relat. Res., 250:234-40, 1990.

Kamakura, S.; Nakajo, S.; Suzuki, O. \& Sasano, Y. New scaffold for recombinant human bone morphogenetic protein-2. J. Biomed. Mater. Res. A., 71:299-307, 2004.

Katagiri, T.; Yamaguchi, A.; Ikeda, T.; Yoshiki, S.; Wozney, J. M.; Rosen, V; Wang, E. A.; Tanaka, H.; Omura, S. \& Suda, T. The non-osteogenic mouse pluripotent cell line, C3H10T1/2, is induced to differentiate into osteblastic cells by recombinant human bone morphogenetic protein-2. Biochem. Biophys. Res .Commum., 172:2959, $1990 \mathrm{~b}$.

Kawamura, M; Iwata, H.; Sato, K. \& Miura. Chondroosteogenetic response to crude bone matrix proteins bound to hydroxyapatite. Clin. Orthop. Relat. Res., 217:281-92, 1987.

Keskin, D. S.; Tezcaner, A.; Korkusuz, P.; Korkusuz, F. \& Hasirci, V. Collagen-chondroitin sulfate-based PLLASAIB- coated rhBMP-2 delivery system for bone repair. Biomaterials., 26:4023-34, 2005.

Kingsley, D. M. The TGF-B superfamily: new members, new receptors, and new genetic tests of function in different organisms. Genes and Development., 8:133-46, 1994.

Kusumoto, K.; Bessho, K.; Fujimura, K.; Konishi, Y.; Ogawa, Y. \& Iizuka, T. Comparative study of bone marrow induced by purified BMP and recombinant human BMP2. Biochemical Biophysical Research Communications., 215: 205-11, 1995.

Lee, S. C.; Shea, M. \&Battle, M. A. Healing of large segmental defects in rat femurs is aided by rhBMP-2 in PLGA matrix. J. Biomed. Mater. Res., 28:1149-156, 1994.

Lindholm, T. C.; Lindholm, T. S.; Alitalo, I. \& Urist, M.R.
Bovine bone morphogenetic protein (bBMP) induced repair of skull trephine defects in sheep. Clin. Orthop. Relat. Res., 277:265-8, 1988.

Marden, L. J.; Hollinger, J. O.; Chaudhari, A; Turek, T.; Schaub, R. G. \& Ron, E. Recombinant human bone morphogenetic protein-2 is superior to demineralized bone matrix in repairing craniotomy defects in rats. $J$. Biomed. Mater. Res., 28:1127-138, 1994.

Mark, D. E.; Hollinger, J. O.; Hastings, C. Jr.; Chen, G; Marden, L. J.; Reddi, A. H. Repair of calvarial nonunions by osteogenin, a bone inductive-protein. J. Plastic. Reconstr. Surg., 86:623-30, 1990.

Matsuo, T.; Sugita, T.; Kubo, T.; Yasunaga, Y.; Ochi, M. \& Murakami, T. Injectable magnetic liposomes as a novel carrier of recombinant human BMP-2 for bone formation in a rat bone-defect model. J. Biomed. Mater. Res. A., 66:747-54, 2003.

Moore, J. C.; Matukas, V. J.; Deatherage, J. R. \& Miller, E.J. Craniofacial osseous restoration with osteoinductive proteins in a collagenous delivery system. Int. J. Oral. Maxillofac. Surg., 19:172-6, 1990.

Nawata, M.; Wakitani, S.; Nakaya, H.; Tanigami, A.; Seki, T.; Nakamura, Y.; Saito, N.; Sano, K.; Hidaka, E. \& Takaoka, K. Use of bone morphogenetic protein 2 and diffusion chambers to engineer cartilage tissue for the repair of defects in articular cartilage. Arthritis. Rheum., 52:155-63, 2005.

Nilsson, O. S. \& Urist, M. R. Immune inhibition of repair of canine skull trephine defects implanted with partially purified bovine morphogenetic protein. Int. Orthop., 15:256-63, 1991.

Noda, M. \& Rodan, G. A. Type-b transforming growth factor inhibits proliferation and expression of alkaline phosphatase in murine osteoblastic-like cells. Biochem. Biophys. Res. Commun., 140:56-65, 1986.

Peterson, B.; Zhang, J.; Iglesias, R.; Kabo, M.; Hedrick, M.; Benhaim, P. \& Lieberman, J. R. Healing of critically sized femoral defects, using genetically modified mesenchymal stem cells from human adipose tissue. Tissue Eng., 11:120-9, 2005.

Rauch, F.; Lauzier, D.; Croteau, S.; Travers, R.; Glorieux, F. H. \& Hamdy, R. Temporal and spatial expression of bone morphogenetic protein-2, 4 e 7 during distraction osteogenesis in rabbits. Bone., 27:453-9, 2000. 
Reddi, A. H. Bone morphogenetic proteins: an unconventional approach to isolation of first mammalian morphogens. Cytokine and Growth Factor Reviews., 8:11-20, 1997.

Reddi, A. H. \& Cunningham, N.S. Initiation and promotion of bone differentiation by bone morphogenetics proteins. J. Bone. Miner. Res., 8:S499-502, 1993.

Ripamonti, U. The morphogenesis of bone in replicas of porous hydroxyapatite obtained from conversion of calcium carbonate exoskeleton of coral. J. Bone .Joint. Surg., 73-A: 692-703, 1991.

Rosen, V.; Cox, K. \& Hattersley, G. Bone morphogenetic proteins. In: Bilezikian J.P., Raisz LG, and Rodan GA., Eds. Principles of bone biology. San Diego, Academic, 1996. pp. 661-71

Sampath, T. K. \& Reddi, A.H. Dissociative extraction and reconstruction of extra-cellular matrix components involved in local bone differentiation. Proc. Natl. Acad. Sci. USA., 78:7599-603, 1981.

Sampath, T. K.; Ozkaynak, E.; Jones, W. K.; Sasak, H.; Tucker, R.; Tucker, M.; Kusmik, W.; Lightholder, J.; Pang, R.; Corbett, C.; Oppermann, H. \& Rueger, D.C. Recombinant human osteogenic protein (hOP-1) induces new bone formation with a specific activity comparable to that of natural bovine OP. Trans. Orthop. Res. Soc., 17:72, 1992.

Sato, K. \& Urist, M. R. Induced regeneration of calvaria by bone morphogenetic protein (BMP) in dogs. Clin. Orthop. Relat. Res., 197:301-11, 1985.

Sato, T.; Kawamura, M.; Sato, K.; Iwata, H. \& Miura, T. Bone morphogenesis of rabbit bone morphogenetic protein-bound hydroxyapatite-fibrin composite. Clin. Orthop. Relat. Res., 263:254-62, 1991.

Schaub, R. Pharmacology and toxicology of a recombinant human bone morphogenetic protein two/bioerodable particle device for bone healing. Food and Drug Administration Symposium on Wound Healing Agents, April 23, 1993.

Spector, J. A.; Lunchs, J. S.; Mehrara, B. J.; Greenwald, J.A.; Smith, L. P. \& Longaker, M.T. Expression of bone morphogenetic proteins during membranous bone healing. Plast. Reconstr. Surg., 107:124, 2001.

Takaoka, K.; Nakahara, H.; Yoshikawa, H.; Masuhara, K.;
Tsuda, T. \& Ono, K. Ectopic bone induction on and in porous hydroxyapatite combined with collagen and bone morphogenetic protein. Clin. Orthop. Relat. Res., 234: 250-4, 1988.

Takaoka, K.; Koezuka, M. \& Nakahara, H. Telopeptidedepleted bovine skin collagen as a carrier for bone morphogenetic protein. J. Orthop. Res., 9:902-7, 1991.

Toriumi, D. M.; Kotler, H. S.; Luxenberg, D. P.; Holtrop, M. E. \& Wang, E.A. Mandibular reconstruction with a recombinant bone-inducing factor. Arch Otolaryngol Head and Neck Surgery., 117:1101-12, 1991.

Urist, M. R. Bone: Formation by autoinduction. Science., 150:893-9, 1965.

Urist, M. R.; Iwata, H; Ceccotti, P. L.; Dorfman, R.L. et al. Bone morphogenesis in implants of insoluble bone gelatin. Proc. Natl. Acad. Sci. USA., 70:3511-5, 1973.

Urist, M. R.; Mikulski, A. \& Lietze, A. Solubilized and insolubilized bone morphogenetic protein. Proc. Natl. Acad. Sci. USA., 76:1828-32, 1979.

Urist, M. R.; Nilsson, O.; Rasmussen, J.; Hirota, W.; Lovell, T.; Schmalzreid, T. \& Finerman, G.A.M. Bone morphogenetic protein (BMP) beta tricalcium phosphate (TCP) composite in skull trephine defects in dog. Clin. Orthop. Relat. Res., 214:295-304, 1987b.

Urist, M. R. Bone morphogenetic protein: The molecularization of skeletal system development. $J$. Bone. Minerv. Res., 12:343, 1997.

Wang, E. A.; Rosen, V.; D’Alessandro, J. S.; Bauduy, M.; Cordes, P.; Harada, T.; Israel, D.; Hewick, R. M.; Kerns, K.; Lapan, P.; Luxenberg, D. P.; Mcquaid, D.; Moutsatsos, I.; Nove, J. \& Wozney, J. M. Recombinat human bone morphogenetic protein induces bone formation. Proc. Natl. Acad. Sci. USA., 87:2220-4, 1990.

Wozney, J. M. Bone morphogenetic proteins. Prog. Growth. Factor. Res., 1:267-80, 1989.

Wozney, J. M. Using purified protein to clone its gene. Methods. Enzymol., 182:738-51, 1990.

Wozney, J. M. The potential role of bone morphogenetic proteins in periodontal reconstruction. J. Periodontol., 66: 506-10, 1995. 
Wozney, J. M. BMPs: roles in bone development and repair. Portland Bone Symposium; Aug 2-5, 1995; Portland, Ore.

Yamaguchi, A.; Katagiri, T.; Ikeda, T.; Wozney, J. M.; Rosen, V.; Wang, E. A.; Kahn, A. J.; Suda, T. \& Yoshiki, S. Recombinant human bone morphogenetic protein-2 stimulates osteoblastic maturation and inhibits myogenic differentiation in vitro. J. Cell. Biol., 113:681-7, 1991.

Yamazaki, Y.; Oida, S.; Akimoto, Y. \& Shioda, S. Response of the mouse femoral muscle to an implant of a composite of a bone morphogenetic protein and plaster of Paris. Clin. Orthop. Relat. Res., 234: 240-9, 1988.

Yasko, A. W.; Lane, J. M.; Fellinger, E. J.; Rosen, V.; Wozney, J. M. \& Wang, E. A. The healing of segmental bone defects, induced by recombinant human bone morphogenetic protein (rhBMP-2). A radiographic, histological and biomechanical study in rats. J. Bone. Joint. Surg., 74A:659-71, 1992.

Zellin, G. \& Lindhe, A. Importance of delivery systems for growth-stimulatory factors with osteopromotive membranes. An experimental study using a mandibular defects. J. Biomed. Mater. Res., 35:181-90, 1997.
Corresponce to:

Dr. João Paulo Mardegan Issa

Rua Garibaldi, 806, ap-601

CEP: $14010-170$

Bairro: Centro

Ribeirão Preto- SP,

BRASIL

Pfone: 55(16)9717-0509,

Email:jpmissa@forp.usp.6r

Received: 27-02-2006

Accepted: 16-05-2006 